\title{
Clinical significance of antibodies to native DNA as measured by a DNA binding technique in patients with articular features of rheumatoid arthritis
}

\author{
DAVID M. GRENNAN, DIANE SLOANE, AMINA BEHAN, AND W. CARSON DICK
}

From the Centre for Rheumatic Diseases and University Department of Medicine, Glasgow Royal Infirmary and the University Department of Pathology, Western Infirmary, Glasgow

SUMMARY The clinical significance of antinative DNA antibodies as measured by the Farr test was investigated in 10 patients with the articular features of rheumatoid arthritis. 5 of these patients also 0 satisfied criteria for a diagnosis of systemic lupus erythematosus (SLE) and might be classified as rheumatoid/lupus overlap syndromes or as rheumatoids with systemic complications. None had ${ }^{-}$ evidence of renal disease and 3 of the 5 had Sjgøren's syndrome. The sixth patient had aggressiveo peripheral arthritis, alopecia, and Sjøgren's syndrome and developed anti-DNA antibodies aftere treatment with penicillamine. All of the 4 rheumatoid patients with no clinical features typical of SLE had some special disease feature. The first had subclinical liver disease and the other 3 had Sjøgren's syndrome in addition to localized vasculitic skin ulceration (2) and pulmonary fibrosis (1) $\searrow$

The occurrence of antibodies to DNA in the sera of patients with systemic lupus erythematosus (SLE) had been known since 1957 (Cepellini et al., 1957). Antibodies to native DNA but not those to denatured DNA have been said to be specific to SLE and to be of use in the diagnosis and management of patients with this condition (Hughes, 1971; Schur and Sandson, 1968; Pincus et al., 1969; Koffler et al., 1971). DNA antibodies have been shown using a number of techniques including complement fixation (Schur and Sandson, 1968), haemagglutination inhibition (Koffler et al., 1971), gel diffusion (Arana and Seligmann, 1967), and the Farr test using an ammonium sulphate precipitation technique and radiolabelled native DNA antigen (Pincus et al., 1969).

All these methods may be criticized on the grounds that native DNA is easily contaminated with singlestranded DNA, thus lowering the selectivity of the test. Purity of the DNA antigen has been improved by various laboratory techniques including the use of a supposedly pure native DNA from the mitochondria of flagellates (Aarden et al., 1975). However, in view of its advantages, including sensitivity, ease of quantification, and availability, the Farr test using radiolabelled $E$. coli DNA as antigen, is the

Accepted for publication April 27, 1976

Correspondence to Dr. D. M. Grennan, The Centıe for Rheumatic Diseases, Baird Street, Glasgow G4 DSF method widely used in clinical practice to measure antibodies to native DNA. Previous studies using\% this technique have found raised DNA antibodyo levels unassociated with SLE in a few patients with Sjøgren's syndrome (Hughes, 1971; Whaley et al. 1973b), chronic active hepatitis (Hughes, 1975 Holian et al., 1975), rheumatoid arthritis witlo pulmonary fibrosis or vasculitis (Holian et al., 1975) and in one patient with Q fever endocarditis (Hughes 1975). The present study examined the significance of raised DNA binding levels in patients with a primary. diagnosis of rheumatoid arthritis.

\section{Patients}

Sera from 200 patients with the articular features of definite rheumatoid arthritis as defined by the ARA criteria (Ropes et al., 1959) and who had positive antinuclear factors $(1 / 16)$, cutaneous vasculitis, of subcutaneous nodules were examined. The 10 patients studied in detail with DNA antibodies alb had DNA binding abnormalities shown in bloof specimens collected on more than one occasion Sjøgren's syndrome was diagnosed when in addition? to the articular disease there was either keratocon-0 junctivitis sicca or diminished salivary flow rates. with grade 4 lymphocytic infiltration of labial salivars gland biopsy. The methods used here were asD described previously (Whaley et al., 1973a). 


\section{Laboratory methods}

DNA binding levels were measured using labelled $E$. coli native DNA as antigen (Radiochemical Centre, Amersham) and using methods previously reported (Webb, et al., 1974). The normal range for the laboratory is $0-25 \%$.

Serum antinuclear factor was measured by an indirect immunofluorescent antibody test using fourfold dilutions to obtain a titre (Beck, 1961). Serum rheumatoid factor was measured using the R3 titration kit (Denver laboratories). Antimitochondrial antibody and smooth muscle antibody were sought using an indirect immunofluorescent technique with rat kidney and rat stomach as substrates, respectively.

\section{Results}

The clinical features of the 10 patients studied are summarized in the Table. All these patients have had a symmetrical peripheral polyarthritis with synovial hypertrophy over a period of years, and radiological evidence of either loss of joint space or erosions.

The first 5 patients in the Table also had at some time manifested three of the clinical features included in the preliminary criteria of the ARA (Cohen et al., 1971) for a diagnosis of SLE, and if the positive antinuclear factor (ANF) $(1 / 256$ or $1 / 1000)$ of all these patients is accepted as the fourth criterion instead of LE cells then all 5 patients on these criteria qualified for a diagnosis of SLE.

Three of these 5 patients had Sjøgren's syndrome. All have had repeatedly normal urine microscopy, creatinine clearance, and quantitative proteinuria estimations. Cases 1-4 at present are well on low doses of steroids, while the fifth patient is developing breathlessness because of interstitial pulmonary involvement.

The sixth patient had a 13-year history of rheumatoid arthritis with symptomatic Sjøgren's syndrome and a 3-year history of Raynaud's phenomenon and alopecia. Before treatment with penicillamine she had active joint disease which had been treated with indomethacin and salicylates, her ANF was positive at $1 / 1000, \mathrm{R} 3$ was positive at $1 / 2048$, and DNA binding was within normal limits at $10 \%$. Penicillamine was begun at $250 \mathrm{mg}$ daily and increased gradually $1 \mathrm{~g} /$ day over a 4-month period. No side effects were noted and there was no proteinuria, but after 6 months the DNA binding was $37 \%$ and 1 month later $64 \%$. At this stage her joint symptoms had improved marginally if at all and penicillamine therapy was stopped.

Case 7 had a 16-year history of a deforming, peripheral polyarthritis. Her serum was persistently

Table Salient features of 10 patients with abnormal DNA binding

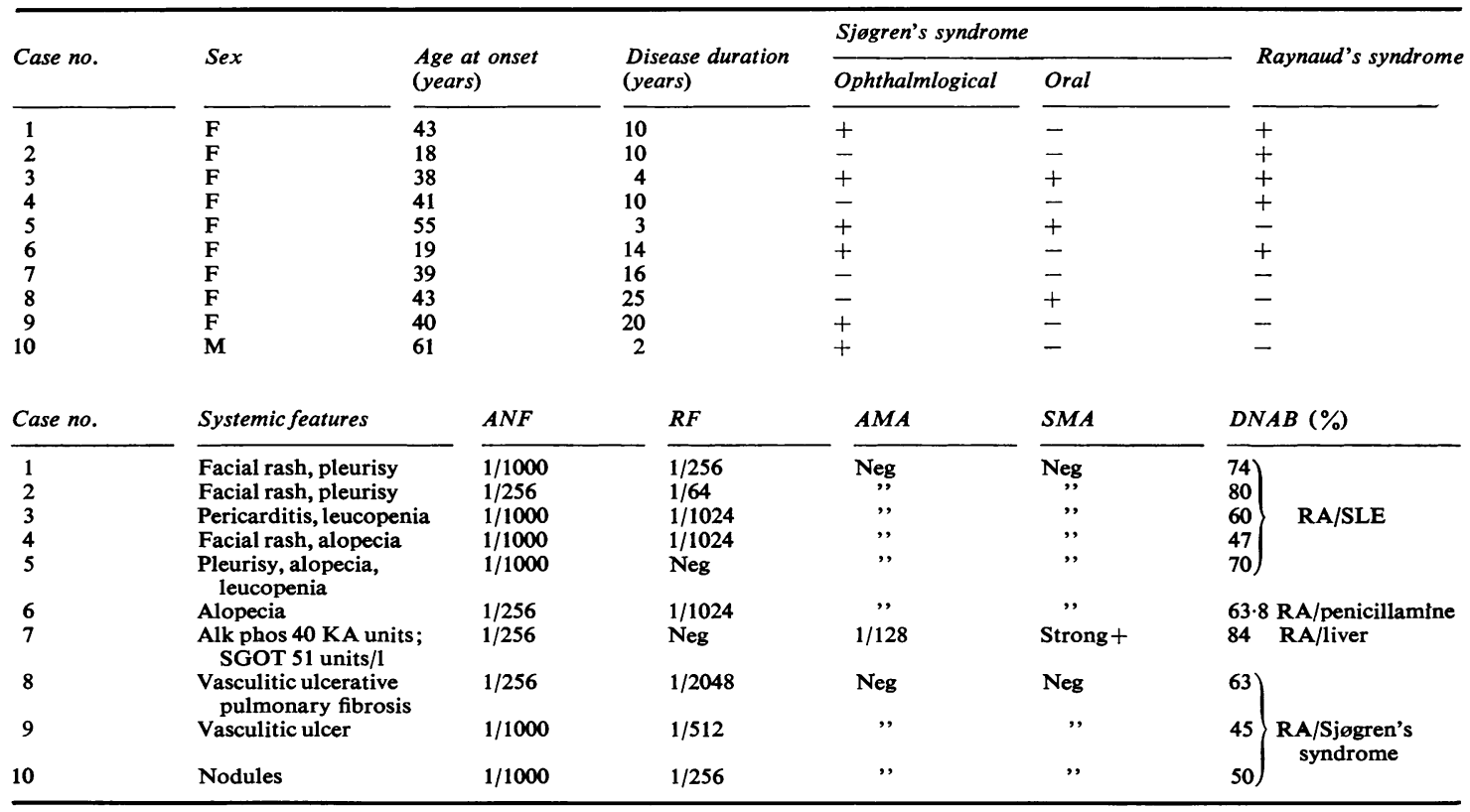

$\mathbf{A N F}=$ antinuclear factor; $\mathbf{R F}=$ rheumatoid factor; $\mathbf{A M A}=$ antimitochondrial antibody; SMA $=$ smooth muscle antibody; $\mathbf{D N A B}=\mathbf{D N A}$ binding. 
1legative for rheumatoid factor while the ANF was strongly positive, as were smooth muscle antibody and antimitochondrial antibody tests. Urea and electrolytes were normal and intravenous pyelography showed a left renal calculus. Serum alkaline phosphatase was raised at 65 King-Armstrong units and serum aspartate aminotransferase was raised at 59 units/1 (normal 0-60) while the bilirubin level was normal. Liver biopsy has not yet been carried out.

Cases 8,9 , and 10 all have had strongly positive ANF and rheumatoid factor. Cases 8 and 9 have had vasculitic leg ulcers, while Case 8 has had radiographic evidence of pulmonary fibrosis, pulmonary function tests showing the diffusion capacity to be reduced at $58 \%$ of the predicted value by the single breath technique. Case 10 has had no evidence of cutaneous vasculitis nor of pulmonary fibrosis to date but has several subcutaneous nodules. Cases 8-10 have no clinical or biochemical evidence of renal disease; all have Sjøgren's syndrome.

\section{Discussion}

Ten patients had the joint features of rheumatoid arthritis in association with repeated high antinative DNA antibody levels in their sera as measured by a DNA binding technique. $9 \%$ contamination of the native DNA test antigen with single-stranded DNA occurs (Radiochemical Centre, Amersham data), and it seems unlikely that this degree of contamination alone would account for the raised DNA binding levels observed. Accepting the fact that this point is unproved, it still seems important to examine the significance of an abnormal result produced by this widely used technique in patients with apparent rheumatoid joint disease.

The first 5 patients all had three clinical features included in the preliminary criteria of the ARA for a diagnosis of SLE (Cohen et al., 1971) in association with high titre positive antinuclear factors. None of them has had biochemical or clinical evidence of renal disease though none has had renal biopsy. It might be argued that they may develop florid renal disease in the future, but in the 3 patients with a disease duration of 10 years this seems unlikely. Whether these patients should be regarded as having a rheumatoid/lupus overlap syndrome ('rheupus'), or whether they should be regarded as having rheumatoid disease with systemic complications is debatable. The potentially benign nature of this type of disease is illustrated by the current good health of Cases 1-4, although the fifth patient is becoming increasingly breathless because of interstitial pulmonary involvement. In all 4 patients, as in the others discussed here, except Case 5, the joint complaint has become the major factor to be con- $\frac{0}{\omega}$. sidered in their management.

The sixth patient had a destructive arthritis, $\overrightarrow{\vec{F}}$ Sjøgren's syndrome, and two features commonly occurring in SLE, alopecia and Raynaud's pheno-듬 menon, before treatment with penicillamine. The $\overline{\bar{\omega}}$ rise in DNA antibody followed 6 months' treatment $\widehat{\sigma}$ with penicillamine and it is likely that this drug was responsible for producing the antibodies. Penicil- $\infty$ lamine has been reported as inducing a lupus-like $\vec{\circ}$ syndrome in patients treated for cystinuria (Oliver et al., 1972), and Wilson's disease (Walshe, 1975). ${ }^{\omega}$ 2 patients out of 4 with rheumatoid arthritis who@ developed a myasthenic syndrome after treatment? with penicillamine also had Sjøgren's syndrome (Bucknall et al., 1975) and these patients are morelikely to develop side effects after penicillamine 0 therapy than after treatment with antibiotics 의 (Whaley, 1973a). Penicillamine therapy in ourpatient probably precipitated anti-DNA antibody production in a predisposed individual.

None of the last 4 patients had had any of the clinical features usually regarded as typical of SLE. All, however, had some other finding with which $\overrightarrow{0}$ their raised DNA binding levels may have been $\forall$ associated. Thus Case 7 had definitely positive tests for mitochondrial and smooth muscle antibodies as well as biochemical evidence of liver disease. DNA antibodies have been described in association with chronic active hepatitis and biliary cirrhosis (Holian $\bar{D}$ et al., 1975; Hughes, 1975) and it is likely that subclinical liver disease was a significant feature in this case. 2 of the last 3 patients had localized vasculitic skin ulceration and one had asymptomatic pulmonary fibrosis, both of which features have been described in association with abnormal DNA bind- $\frac{0}{2}$ ing levels in patients with rheumatoid arthritis (Holian et al., 1975). All 3 also had Sjøgren's syndrome, in which DNA antibodies have also been reported (Whaley et al., 1973b; Hughes, 1971). None of these last 4 patients had clinical or biochemicalo evidence of renal lupus, although we did not regard it as justifiable to carry out renal biopsy.

It has been shown that DNA antibodies may be induced by treatment with phenylbutazone (Grayson, $\sigma$ et al., 1975). None of the patients reported here had N received this or related drugs although most of them N had received treatment with indomethacin or 0 salicylates before anti-DNA antibodies were shown in their sera. Gold therapy in the last patient was started after DNA antibodies had been shown. Thus, $\stackrel{\infty}{\rightarrow}$ apart from Case 6, previous drug therapy could not 0 be clearly implicated as a mechanism for DNA antibody production.

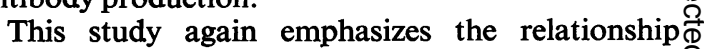
between Sjøgren's syndrome and both DNA anti- 
bodies and rheumatoid/SLE overlap syndromes, a factor that was ignored in two recent studies of patients with rheumatoid/SLE overlap syndromes (Go and Lockshin 1975; Astapenko et al., 1975). Thus 7 out of the 10 patients described here, 4 with rheumatoid/SLE overlap syndromes and 3 with rheumatoid arthritis, had Sjøgren's syndrome. If the concept of a spectrum of connective tissue diseases with typical rheumatoid arthritis and typical SLE at the poles is accepted, it may be that rheumatoid patients with Sjøgren's syndrome tend to lie near the middle. This concept may have clinical significance as many Sjøgren's patients have mutliple drug allergy and unwise antibiotic therapy may precipitate florid active SLE in patients with previously benign disease (Grennan et al., 1975).

In some but not all patients with typical SLE the DNA binding level may provide a guide to disease activity (Schur and Sandson, 1968). In only one of our patients (Case 3) has the DNA binding level been found to rise and fall in parallel with changes in disease activity and in her it has been extra-articular features of the disease and pyrexia which in particular have paralleled DNA binding levels. In the other patients DNA binding has shown no clear-cut relationship to either articular or extra-articular features of disease activity.

We conclude that (1) antinative DNA antibodies occur in diseases other than typical SLE; (2) patients with rheumatoid arthritis in whom they occur have either clinical features suggestive of SLE, Sjøgren's syndrome, or some other disease feature but often have no evidence of renal disease; (3) anti-DNA antibody levels often do not correlate with disease activity.

D.M.G. is in receipt of a Robins Clinical Research Fellowship.

\section{References}

Aarden, L. A., Lakmaker, F., de Groot, E. R., Swaak, A. J. G., and Feltkamp, T. E. W. (1975). Detection of antibodies to DNA by radioimmunoassay and immunofluorescence. Scandinavian Journal of Rheumatology, Suppl. 11, 12-19.

Arana, R., and Seligmann, M. (1967). Antibodies to native and denatured deoxyribonucleic acid in systemic lupus erythematosus. Journal of Clinical Investigation, 46, 1867 . 1822.

Astapenko, M. G., Nassonova, V. A., Gritsman, N. N., Speransky, A. I., and Surovtseva, V. M. (1975). Mixed forms of rheumatoid arthritis and systemic lupus erythematosus. (Abst.) Scandinavian Journal of Rheumatology, Suppl. 8, 2-8.

Beck, J. S. (1961). Variations in the morphological pattern of autoimmune nuclear fluorescence. Lancet, 1, 1203.
Bucknall, R. C., Dixon, A. St. J., Glick, E. N., Woodland, J., and Zutshi, D. W. (1975). Myasthenia associated with penicillamine treatment for rheumatoid arthritis. British Medical Journal, 1, 600-602.

Cepellini, R., Polli, E., and Cellada, F. (1957). A DNAreacting factor in serum of a patient with lupus erythematosus diffusus. Proceedings of the Society for Experimental Biology and Medicine, 96, 52.

Cohen, A. S., Reynolds, W. E., Franklin, E. C., Kulka, J. P., Ropes, M. W., Shulman, L. E., and Wallace, S. L. (1971). Preliminary criteria for the classification of systemic lupus erythematosus. Bulletin on Rheumatic Diseases, 21, 643-648.

Go, T., and Lockshin, M. (1975). Latex-negative ANApositive erosive arthritis: prognosis more like SLE than RA. 39th Annual Meeting of the American Rheumatism Association Section of the Arthritis Foundation.

Grayson, M. F., Martin, V. M., and Markham, R. L. (1975). Antinative DNA antibodies as a reaction to pyrazole drugs. Annals of the Rheumatic Diseases, 34, 373-375.

Grennan, D. M., Bell, G., Rooney, P. J., and Kennedy, A. C. (1975). SLE precipitated by antibiotics in a patient with Sjøgren's syndrome and rheumatoid arthritis. British Medical Journal, 4, 385.

Holian, J., Griffiths, I. D., Glass, D. N., Maini, R. N., and Scott, J. T. (1975). Human anti-DNA antibody reference standards for diagnosis and management of systemic lupus erythematosus. Annals of the Rheumatic Diseases, 34, 438-443.

Hughes, G. R. V. (1971). Significance of anti-DNA antibodies in systemic lupus erythematosus. Lancet, 2, 861-863.

Hughes, G. R. V. (1975). Frequency of anti-DNA antibodies in SLE, RA and other diseases. Scandinavian Journal of Rheumatology, Suppl. 11, 42-51.

Koffler, D., Carr, R., Agnello, V., Thoburn, R., and Kunkel, H. G. (1971). Antibodies to polynucleotides in human sera: antigenic specificity and relation to disease. Journal of Experimental Medicine, 134, 294-312.

Oliver, I., Liberman, V. A., and De Vries, A. (1972). Lupuslike syndrome induced by penicillamine in cystinuria. Journal of the American Medical Association, 220, 588.

Pincus, T., Schur, P. H., Rose, J. A., Decker, J. L., and Talal, N. (1969) Measurement of serum DNA-binding activity in systemic lupus erythematosus. New England Journal of Medicine, 281, 701-705.

Ropes, M. W., Bennett, G. A., Cobb, S., Jacox, R., and Jessar, R. A. (1959). 1958 revision of diagnostic criteria for rheumatoid arthritis. Annals of the Rheumatic Diseases, $18,49$.

Schur, P. H., and Sandson, J. (1968). Immunological factors and clinical activity in systemic lupus erythematosus. New England Journal of Medicine, 278, 533-538.

Walshe, J. M. (1975). Adverse effects of penicillamine in relation to the indications for treatment. Symposium at St. Bartholomew's Hospital, London, October 26, 1975.

Webb, J., Whaley, K., and Lee, P. (1974). Clinical significance of native DNA antibodies in systemic lupus erythematosus and other connective tissue diseases. Scottish Medical Journal, 19, 171-175.

Whaley, K., Williamson, J., Chisholm, D. M., Webb, J., Mason, D. K., and Buchanan, W. W. (1973a). Sjøgren's syndrome. I. Sicca components. Quarterly Journal of Medicine, 42, 279-304.

Whaley, K., Webb, J., McAvoy, B. A., Hughes, G. R. V., Lee, P., MacSween, R. N. M., and Buchanan, W. W. (1973b). Sjøgren's syndrome. II. Clinical associations and immunological phenomena. Quarterly Journal of Medicine, 42, 513-548. 